\title{
パルプ紙製造用薬品類 (2)
}

\section{Chemicals for Pulp and Paper Making (2)}

\section{B. 紙板紙製造用蔡品類}

紙や板紙はパルプ繊維が結合して構成したシートの みでは，未来の性質を現わすことができないので，色 々の非纎維物を製造工程中に添加する。例光ば媜料を 用いてパルプ繊維の間の空所を充填したり，サイズ剂 を利用してインキのにじみを制限したり，湿気や液体 等の浸入，浸出に耐性を与光たりしていることなどは， 古くから行われてきている。近年になってパルプ繊維 の資源が，針葉樹から広葉樹への移行が多くなってき たことに対応して，鉱物質資源の添加，塗被に使われ る薬品の割合も増大し，合成樹脂類の応用なぞも目ざ ましくなってきている。

一方，最新の製紙設備は益々大型，高速化してきて 機械的に巧妙となり, 薬品類の添加物, 再用水, 故紙 等の使用量増大化と，それらに伴ら排出物質の処理用 薬品も発達してきている。

しかしながら，古くから用いられてきた添加物の大 部分の種類のものは, 依然として利用されている。

従って，古くから使われてきている主要非繊維物に ついて，まず記して和く。

\section{古くから利用されてきている主要非絨維物}

媜 料

各種の紙を製造するのに，配合原料の一つとして填

第3 表 各種の紙に対して添加される填料の種類 と添加率の例 ${ }^{(1)}$

\begin{tabular}{|c|c|c|}
\hline 紙の種別 & 墳料の種 類 & 添加率\% \\
\hline 筆 記 用 紙 & 不透明性の高い顔料とク & $1-6$ \\
\hline 書籍用紙 & $\begin{array}{l}\text { クレーと不透明性の高い } \\
\text { 顔料 }\end{array}$ & $5-40$ \\
\hline オフセット用 & 同上 & $0-10$ \\
\hline 煙草巻紙 & 高純度の炭酸カルシウム & $35-40$ \\
\hline 騰写版原紙 & $\begin{array}{l}\text { クレーと珪藻土に高不透 } \\
\text { 明顔料 }\end{array}$ & $20-25$ \\
\hline 封筒用紙 & $\begin{array}{l}\text { 多儿ク又はクレーに高不 } \\
\text { 透明顔料 }\end{array}$ & $10-20$ \\
\hline 新聞印刷紙 & クレー又は炭酸カルシウ & $2-4$ \\
\hline バイブル用紙 & 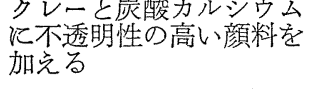 & $20-30$ \\
\hline
\end{tabular}

$$
\begin{array}{ccc}
\text { 小 } \\
\text { Nobuyoshi }
\end{array} \underset{\text { Koizumi }}{\text { 小信 }}
$$

料がある。垻料は鉱物質粉末である。

填料を混合する目的は周知の如く(a)不透明性を增す。 (b)印刷適性を改善する。(c)白色度を向上させる。(d)其 の他の性質即ち, 吸収性, 柔軟性, 密度等の増加, ま たは煙草巻紙では燃焼性を調整する等にある。

各種の紙対して, 添加される媜料の種類や添加率 の例は第 3 表倸示如くで㐫る。

この表に示す如く，填料としてはクレーが最も使用 されている。

な特，煙草巻紙のそなえるべき重要な性質として， 燃焼性がある。すなわち，煙草の葉と巻紙とは同時に 然焼してゆくことが必要であるので, 微量の助然剤も 添加されることがあるが，更に無味無臭，水に強く， のり付けのよいこと等も要求される。

炭酸カルシウムの役割は, この場合煙草巻紙の燃焼 を助悩，紙質としては充分飞空吵を保ちかつ，不透明 性を高くすることにあるのである。

\section{クレー}

クレーはまた白土ともいい，製紙用には，原土を水 ヒして混在している不純物を除去して精製したもので 㐫る。産地や精製方法の差によってその性質を異にし ている。

化学的には，Al と Si の酸化物が主成分であるが, 粒度は直径 2 ミクロン以下の粒子の割合の多いもの, 白色度の高いもの, 不純分の混合率の少いもの等吕良 品とされている。

\section{塤料の添加による逆効果}

紙料に埧料を添加することにより製品に対して，前 記の如く種々の效果をもたらすが，一面，紙の強度性， 印刷適性, サイズ度の低下，シャドウ・マークの生成， 抄紙機のワイヤの寿命等にわるい影響を与光ることも， わ初の経験しているところで㐫る。従って採用す る品種や品質の選択や添加率の決定等に特段の注意を 必要とする斿で莗る。

紙の強度性に対して, 填料の含有率の影響安研究し たのによると第 4 表の如き逆効果をあげている。

この表の示すように，一定のパルプを配合した紙の 強度汃低下していくのは, 纎維と繊維の結合力が減少 するためで少ると説明されている。 
第 4 表 紙の強度に対する填料の影響 ${ }^{(2)}$

\begin{tabular}{|c|c|c|c|}
\hline \multirow{2}{*}{$\begin{array}{l}\text { 強 度 性 } \sum^{\text {品 }} \\
\text { 填 料 }\end{array}$} & \multicolumn{3}{|c|}{$\begin{array}{l}\text { 一定坪量に対する } \\
\text { 填料含有率 }\end{array}$} \\
\hline & $10 \%$ & $20 \%$ & $30 \%$ \\
\hline 引張強度 \% & & & \\
\hline セツコウ (石膏) & 90 & 76 & 60 \\
\hline クレー & 82.5 & 60 & 47.5 \\
\hline 破裂強度 $\%$ & & & \\
\hline セツコウ(石膏) & 90 & 75 & 60 \\
\hline クレー & 72 & 54 & 37 \\
\hline 引裂強度 $(\%)$ & & & \\
\hline すべての填料 & 92.5 & 77 & 67 \\
\hline 耐折度\%(ショッパー) & & & \\
\hline 硫化西鉛 & 57 & 24 & 10 \\
\hline クレー & 23 & 7 & 2 \\
\hline
\end{tabular}

ロジンサイズ

紙は元来，多孔質で液体を吸収する性質をもってい るシートであるから，この性質を利用する場合もある が，紙，板紙の大部分の用途では，この吸収性を制限 する必要がある。

この目的のために，内部にをたは表面に存在してい る空吵を, 耐水性の膠質物質でろさいで, 液体の浸入 を防ぐ薬品類が利用される。それがサイズである。

サイズを利用する方法には周知の如く, 内部サイズ と表面サイズの 2 つがある。

内部サイズには，一般にロジン石けんやワックス乳 化物を用いる。

これらが工業的には最も重要されているけれども, そのほかは CMC, 殿粉, 合成樹脂等も比較的少量で あるが添加されることもある。

また，表面サイズ用としては，殿粉類，二カワ(膠) CMC 等が一般的でめった。

今日でもしかし，各種の紙，板紙の大部分は，内部 サイズを施こしたものであろらと考えられている。

内部サイズ用薬品

内部サイズの薬品では (a)ロジン (b)アルカリ

硫酸バンドの三者が主役である。

ロジン

粗松脂を分りらして製出して揮発性のテレピン油を 除いた固形残渣を，ロジン又はコロホニーと称してい

第5表 ロジンの等級と色数（アメリカ式）

\begin{tabular}{|cc|c|c|c|c|c|c|}
\hline 等 & 級 & $\mathrm{X}$ & $\mathrm{WW}$ & $\mathrm{WG}$ & $\mathrm{N}$ & $\mathrm{M}$ & $\mathrm{K}$ \\
\hline 色 & 数 & 12.5 & 19.0 & 24.0 & 29.0 & 36.0 & 44.0 \\
\hline \hline 等 & 級 & $\mathrm{I}$ & $\mathrm{H}$ & $\mathrm{G}$ & $\mathrm{F}$ & $\mathrm{E}$ & $\mathrm{D}$ \\
\hline 色 & 数 & 65.0 & 87.0 & 136 & 240 & 400 & 800 \\
\hline
\end{tabular}

る。日本では大部分をアメリカから輸入てているが, 色は淡黄から赤褐まである。

一般に淡黄色に近いものほど品質は優れている。 ロジンの種類又は等級と色数を，アメリカ式で示し たものは第 5 表の如くである。

本表には，D以下の等級はないが，実際にはBまで あってこれを最下等とし，Xを最上等としている。

これは一般取引上，等級に関する錯詔をさけるため に，各等級に対しては第 6 表のよらな名前が割り当て られ，ふつらその頭文字だけで区別している。

製紙用としては主としてH拈よびIを使用し，クラ フト紙のような色のついたものにF級のものが使われ るといら(3)。

第 6 表 ロジンの等級と名称
B. (Betsy) Com, Strained
C. Strained
I. (Isaac) Good No. one
K. (Kate) Low Pale
F. (Frank) Good No. two
G. (George) Low No. one
H. (Harry) No. one
D. (Dolly) Good Strained
E. (Edward) No. two
M. (Mary) Pale
N. (Nancy) Extra Pale

WG. Window Glass

WW. Water White

\section{Extra Palest}

ロジンの所要量は，紙の種類に対してまちまちであ るが，一般的に $0.5 \%$ 2.5\%の間であろら。特殊の場 合には $5 \%$ も添加することもあるが平均 $2 \%$ ぐらいと 見られる。

アルカリ

ロジンは，たいていのアルカリと作用するけれども， サイズ剂の製造に多く使われるのは, 苛性ソーダとソ 一ダ灰とである。

サイズ剤は，最近市販されているものが多くなって いる。自己の製紙工場に食塩の電解プラントを設けて, 苛性ソーダと塩素を製造しているところもある。電解 プラントで得られた苛性ソーダは, 濃度の低いことや, 食塩を少量混入していることなどの特質がある。

$100 \mathrm{~kg}$ のロジンを完全にけん化するのは，12kg の 苛性ソーダを必要とするが, 遊離ロジンの含有の程度 によって，その量は変ってくる。

ソーダ灰は工業用の無水炭酸ソーダ, $\mathrm{Na}_{2} \mathrm{CO}_{3}$ であ る。 
$100 \mathrm{~kg}$ ロジンに対しソーダ灰 $16 \mathrm{~kg}$ でケん化するこ とができる。第 7 表は，ロジン石けんの遊離ロジンそ の物の割合を，ロジンに対するソーダ灰の添加量別に 示している(4)。

第7表 ロジン石けんの遊離ロジンその他の割合

\begin{tabular}{|c|c|c|c|c|}
\hline ロジン & ソーダ扊 & $\begin{array}{l}\text { 口ジン酸 } \\
\text { ソーダ }\end{array}$ & 遊離ロジン & 全石け九 \\
\hline 100 & 16 & 97.8 & 8.8 & 106.6 \\
\hline 100 & 14 & 85.5 & 20.2 & 105.7 \\
\hline 100 & 12 & 73.3 & 31.6 & 104.9 \\
\hline 100 & 10 & 61.1 & 43.0 & 104.1 \\
\hline 100 & 8 & 48.1 & 54.4 & 103.3 \\
\hline
\end{tabular}

硫酸バンド

硫酸バンドは，製紙工場でも用水の処理，染料の定 着, 紙料混合水の $\mathrm{pH}$ の調整等使用するが，サイズ 剤の定着用には最も重要されていることも周知の如く である。であるから外国では “製紙家のミョウバン” と呼んでいるくらいである。

“製紙家のミョウバン”は厳密な化学的のミョウバ ンを言うのではなく，一般の化学式は $\mathrm{Al}_{2}\left(\mathrm{SO}_{4}\right)_{3}$ で表 わされるものであるが，市販の硫酸バンドは，この理 論的の化学式のほかに $\mathrm{Al}_{2} \mathrm{O}_{3}$ を過剩に含えでいて，こ れは若干アルカリ性である。

固形バンドの市販品を分析した 1 例は次の第 8 表の 如きものである。このほか 14.5 分子の結晶水を含ん でいる。

$\begin{array}{lr}\text { 第 } 8 \text { 表 市販硫酸バンドの分析例 } \\ \text { 組 成 分 } \\ \text { 総 } \mathrm{Al}_{2} \mathrm{O}_{3} & 17.2 \\ \text { 結合 } \mathrm{Al}_{2} \mathrm{O}_{3} & 16.5 \\ \text { アルカリ性 } \mathrm{Al}_{2} \mathrm{O}_{3} & 4.7 \\ \text { 不溶解分 } & 0.07 \\ \mathrm{Fe}_{2} \mathrm{O}_{3} & 0.01 \\ \mathrm{Fe}_{2} \mathrm{O} & 0.35\end{array}$

市販品の品質については JIS 亿子第 9 表の如く規定 されている。

製品は，製紙工場へは液体で供給されているのが多 い。

硫酸バンドを工場で使う場合，最も注意を要するの は，市販品の中に鉄分が含まれている量が，極めて少 いものがよいのであるということである。

$\mathrm{Fe}_{2} \mathrm{O}_{3}$ として新聞用紙炕 $1.0 \%$ ，筆記用紙や書籍 用紙には $0.3 \%$ 以下でならなければならないとされて いる(4)。

感光複写用紙には無鉄バンドを用いなければならな い。勿論，工場の実際操業には，鉄分の混入する原因
は使用する硫酸バンド以外飞る多々あることも考兄ね ばならない。

硫酸バンド液を紙料中へ添加する時期については, ロジンサイズやその他の填料, 殿粉または湿潤強力樹 脂等を加光て，これらが完全に混合し分散してから後 に注ぐのが普通とされている。

工場によっては，抄紙蟣の種ロポンプのサクション 側へ加觉たりしているが，招先くとも最終のジョルダ ンやレファイナーで加党るのがよいとされている。

サイズの沈殿粒子が一度生成されてからは，これら の機械装置による作用を強力に受けても，分解してし まうことはない。抄紙機の種ロポンプ光添加するのは， 紙料の $\mathrm{pH}$ を調整する目的の岁る場合が主であうう。 また，用水の硬度が非常飞高い地域では，サイズ剤を 添加する前に硫酸バンドの一部か全量を注加して，用 水の $\mathrm{pH}$ を中性にして和く方がよい。

板紙工場で，炭酸塩の填料を含しだ故紙空使用して 抄造する場合にサイズを施こしたり，未晒クラフトパ ルプを使用するときなどは紙料は多少アルカリ性にな っているから，硫酸バンドによって，アルカリ性を減 じて拉く方がよいとされている(2)。

硫酸バンドはさらに，製紙用に使用される大部分の 染料を沈殿させ，不溶性染料老生成させて紙中留ま らせる作用もある。

硫酸バンドの所要量は，サイズの使用量，紙料の品 質气の他用水の性質等によって異るが，一般炕イズ 1 部に対して 2 〜 部を用いている。

表面サイズ用薬品

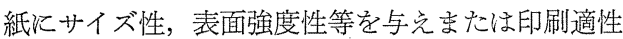
を改善する等の目的で，表面サイズを施こすのに用い る薬品は殿粉やニカワ (膠) であった。最近では殿粉 は変性して使用される傾向が目立ってきた。

膠は合成樹脂代代りつつある。

殿 粉

殿粉は小麦, とうもろこし, 馬鈴薯, タビオカ, 米, サゴ等を原料としているが，その粒子径と形態は，こ れらの原料の種類によって，全く特徴を異にしている。 各種殿粉粒子の形態を示したものは，第11 図 (7) の 如くである。

また，市販の殿粉は水分以外は殆えぞ純粋な多糖類 （殿粉もその一つ）加成っているといえるが，粒の 内外飞少量の蛋白質, 脂肪, 無機質などを伴うのが普 通であるとされている。第 10 表は主な殿粉の組成を 示している(5)。

殿粉はそのままでは，(a)粘度が高い。(b)温度が下る とゲル化する。なぞの理由で変性して使用される。こ 
第 9 表 硫 酸 バンドの 品 質

\begin{tabular}{|c|c|c|c|c|c|c|c|c|c|c|c|c|}
\hline & \multicolumn{4}{|c|}{1} & \multicolumn{2}{|l|}{ 当 } & \multicolumn{4}{|c|}{2} & \multicolumn{2}{|c|}{ 号 } \\
\hline & 特 & 種 & 1 & 種 & 2 & 種 & 特 & 種 & 1 & 種 & 2 & 種 \\
\hline 不 溶 解 分 & 0.1 & \%以下 & 0.2 & \%以下 & 0.2 & \%以下 & 0.1 & \%以下 & 0.2 & \%以下 & 0.2 & \%以下 \\
\hline 遊 離 硫 酸 $\left(\mathrm{H}_{2} \mathrm{SO}_{4}\right)$ & 0.1 & \%以下 & 0.2 & $\%$ 以下 & 0.3 & \%以下 & 0.1 & $\%$ 以下 & 0.2 & $\%$ 以下 & 0.3 & $\%$ 以下 \\
\hline 酸 化 第 二 鉄 $\left(\mathrm{Fe}_{2} \mathrm{O}_{3}\right)$ & 0.0 & $\%$ 以下 & 0.6 & \%以下 & 0.9 & \%以下 & 0.01 & \%以下 & 0.5 & $\%$ 以下 & 0.9 & \%以下 \\
\hline 酸化アルミニウム $\left(\mathrm{Al}_{2} \mathrm{O}_{3}\right)$ & 17.0 & $\%$ 以上 & 17.0 & $\%$ 以上 & 17.0 & $\%$ 以上 & 14.0 & $\%$ 以上 & 14.0 & $\%$ 以上 & 14.0 & $\%$ 以上 \\
\hline
\end{tabular}

第10表 殿 粉 の 組 成

\begin{tabular}{|c|c|c|c|c|c|c|c|}
\hline & $\begin{array}{l}\text { 水 }(\%) \\
(\%)\end{array}$ & $\begin{array}{c}\text { 粒子の大いさ } \\
(\mu)\end{array}$ & $\begin{array}{c}\text { 粗蛋白質 } \\
(\%)\end{array}$ & $\begin{array}{c}\text { 粗脂肪 } \\
(\%)\end{array}$ & $\begin{array}{c}\text { 粗緎維 } \\
(\%)\end{array}$ & $\begin{array}{c}\text { 灰 分 } \\
(\%)\end{array}$ & $\begin{array}{c}\text { 可溶性窒素物 } \\
\text { (主とし殿粉) } \\
(\%)\end{array}$ \\
\hline 米 & 13.71 & $2 \sim 10$ & 0.81 & trace & trace & 0.30 & 85.15 \\
\hline 麦 & 13.94 & $6 \sim 30$ & 1.13 & 0.19 & 0.17 & 0.46 & 84.11 \\
\hline とらもろこし & 13.31 & $15 \sim 30$ & 1.20 & 0.01 & trace & 0.37 & 85.11 \\
\hline 鈴 & 17.76 & $2 \sim 25$ & 0.88 & 0.05 & 0.01 & 0.57 & 80.68 \\
\hline
\end{tabular}

第11図 各種殿粉粒子の形態

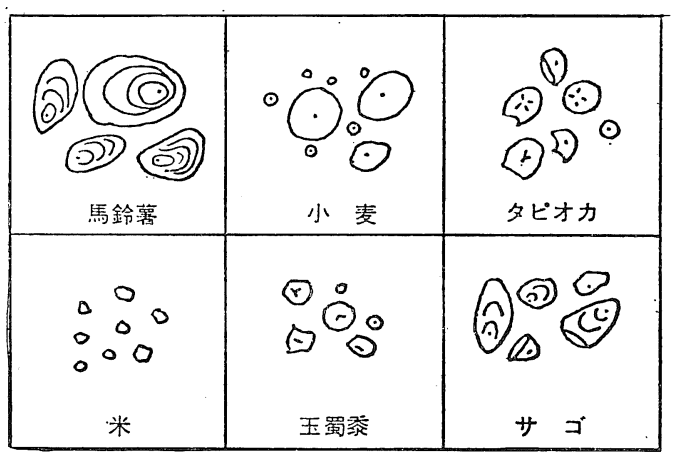

れには酵素変性殿粉，酸化殿粉などがある ${ }^{(6)}$ 。特に表 面サイズ用には粘度が一定で, 経時的に粘度が変化し ない殿粉を用いる必要がある。

ニカワ (膠)

琹は高価であること, 常に一定の品質のものが得ら れにくいことから，歴史的には古くから使われていた が他に安価な変性殿粉，合成樹脂類が一般的になって きた今日は，特殊な場合を除いては，あまり使用され ない(5)という。

\section{着色剂}

紙を着色する方法は，紙料をパルパーやレファイナ 一で連続的に調成している間に添加して行う場合と， シート状に構成させてから表面に施行する場合とがあ るし，また，両方法を行らこともあるが，パルプ状態 にある工程中に着色するのが普通であろう。

製紙工程で，着色を施行する主な目的は周知の如く， 色紙を抄造するためと，着色しない所謂白紙を充分白 色に見えるよらにするためとである。

このように，紙料の色をいろいろ変化せしめる目的
に使用する物質が，染料か顔料である。

染料と顔料との異る点は, 前者は水に可溶性で染色 力が強く, 色調や明度の範囲が広い, 更に紙の強度を 低下させることはない。特に水に可溶性である点は， 紙料中に均斉に添加するためには重要な条件である。

製紙上使用する染料の主なものは合成染料で，酸性 染料, 塩基性染料, 直接染料等がある。これらは溶解 性，価格，有効な $\mathrm{pH}$ の範囲等を異にしている。

各種の染料を選択するに当って, 目的の紙の種類に 応じて堅ろら度を考慮しなければならない。堅ろら度 とは光線, アルカリ, 酸, 塩素和よび離色（にじみ出 し）等に対する耐性の度合である。

しかし，紙の使用目的によっては，堅らら度の高い 高価な染料を選ぶ必要はないことは勿論である。

堅ろら度を比較するのに次のような耐光度試験表を 用いるのが一般化されつつある。この表はフェードオ メータを用いて, 試料を光線にさらして行ら方式で使 用するものである。光線にはカーボンアークを利用す る。光力は太陽光の約 2 倍半它有していて, 一定の温 度, 湿度のもとで試験するようになっている。

節 12 表 耐光度比較表 ${ }^{(8)}$

\begin{tabular}{|c|c|c|}
\hline 耐 光 度 & 退色しない時間 & $\begin{array}{l}\text { 実質的に退色する } \\
\text { 時間 }\end{array}$ \\
\hline 劣 る & - & $1 / 2$ 時間以下 \\
\hline 稍 夕良 & $1 / 2$ 時間 & 2 時間 \\
\hline 良 & $2 \prime \prime$ & $4 \prime \prime$ \\
\hline 非常に良い & $6 \quad \prime \prime$ & $20 \prime \prime$ \\
\hline 優 秀 & $\begin{array}{l}\text { 長時間晒しても影 } \\
\text { 響なし }\end{array}$ & \\
\hline
\end{tabular}

工場では古くから製品の着色に関する技能は，かな りむずかしいので，各種の紙に対し，価格の点からも 
工程の上からも最も適当な染料学選んで, 均斉な染着 のできる人限られている。現在でも不熟練な従業員 には不可能とされているょうである。

\section{近年になって利用されている主要非緎維物}

近年になって，紙や板紙の用途上の改善を要求され ることが益々大きくなってきた。それ䇏応して添加 される非纎維物の化学薬品や鉣物質の種類や需要量も 增してきている。

例えば

（a）湿潤強力紙を製造するために合成樹脂を利用す る。

(b) コート紙用のクレーやカゼイン等の使用量が増 大化している。

(c) 消泡剂やスライムニントロール剤の発達等をう ながしている。そのほかに

（d）植物繊維を原料としているパルプ，紙，板紙， 包装材料等の保存処理を施行するための化学薬品 又は生物学的の研究等も又目ざましくなっている。 このような現象が，近代製紙工業の特徵であるとさ

第 13 表 添加薬品類の分類 $(9)$

\begin{tabular}{|c|c|}
\hline 薬 & 主な効 用 \\
\hline \multicolumn{2}{|l|}{ 湿部へ添加 } \\
\hline $\begin{array}{l}\text { 塩類, アルカリ, 酸 } \\
\text { 強度用接着剂 }\end{array}$ & $\begin{array}{l}\mathrm{pH} \text { 調整, 地合構成, 脱水 } \\
\text { 乾燥强度性の改善 }\end{array}$ \\
\hline 湿潤強力樹脂 & 湿潤強度性の改善 \\
\hline 内部サイズ剤 & 液体浸透度の調整 \\
\hline 維繊羽毛化防止剂 & $\begin{array}{l}\text { シート中に繊維の分散を良 } \\
\text { くする }\end{array}$ \\
\hline 脱水補助剤 & 脱水率增加 \\
\hline 歩留補助剤 & 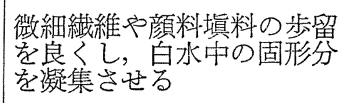 \\
\hline 白色填料 & $\begin{array}{l}\text { 製品の外観を改良乙印刷適 } \\
\text { 性を与を }\end{array}$ \\
\hline 消泡剂 & $\begin{array}{l}\text { 紙料を清浄にし, 地合の構 } \\
\text { 成を改善学る }\end{array}$ \\
\hline 着色材料 & 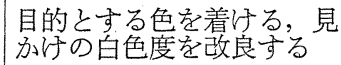 \\
\hline スライム防止剤 & 細菌, 微生物等の発生を抑 \\
\hline $\begin{array}{l}\text { ピッチコントロール } \\
\text { 薬品 }\end{array}$ & $\begin{array}{l}\text { ピッチの蓄積や析出を防止 } \\
\text { する }\end{array}$ \\
\hline 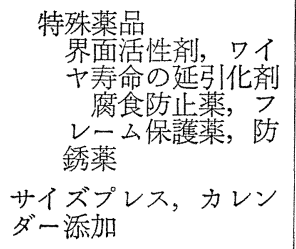 & \\
\hline $\begin{array}{l}\text { 接着剤, フィルム形 } \\
\text { 成重合物 }\end{array}$ & $\begin{array}{l}\text { 表面強度, サイジング，印 } \\
\text { 邻適性等改善 }\end{array}$ \\
\hline
\end{tabular}

れている。

そして，最近の製紙業では製造費の $10 \%$ も薬品費

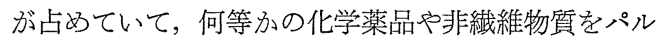
プ繊維に添加しなければ，この産業は成り立たないの である。

\section{添加薬品類の分類}

近代の製紙工程で使用する添加薬品類を分類すると， 第 13 表の如くである。

この表の示す薬品の二三の種類について，注釈を加 壳て拈くこととする。

\section{湿潤強力樹脂}

植物繊維を主としてできている紙や板紙は，周囲の 空気の湿度が高ければ吸湿し, 液中に浸漬すればこれ 吸収する。そして含有水分の増加淿よって，物理的 の性質に種々の影響を与兄るのは周知の通りである。 水中に浸漬して使用する紙の種類には，写真用紙， 青写真用紙，濾紙，含浸加工原紙，ティーバッグ等が あり，ポスター紙，地図用紙，包装函，建築用紙，袋 紙，冷凍食品包装用紙等は外気の湿気に晒されること 多多い。

$$
\text { ペーパータオル，ナフキンその他のテイッシュー等 }
$$
は吸収性をそこなわないでかつ，湿潤強度が高いこと が必要である。

紙の諸性質に対する空気の湿度の影響を研究したも のによると，引張り強度は空気湿度が 30〜 40\% まで は, 湿度の増加とともに増大するが，更に高湿度範团 では急激汇低下するという(10)。

紙や板紙の湿潤強度を与兄更に增大させるのに，メ ラミンフォルムアルデヒド，尿素フォルムアルデヒド 等の合成樹脂が発達してきているのは周知の如くであ るが，元の添加される個所は，樹脂功紙料中に均斉に 分散して，パルプ繊維が膨潤状態にある湿部に执いて 施行するのが最も効果的に作用するという。

メラミンフォルムアルデヒド樹脂で処理した紙と, 無処理の紙とを相対湿度の変っている条件下で, 強度

第14 表，紙の強度に扔上济す湿度の影響

\begin{tabular}{|c|c|c|c|c|}
\hline & \multicolumn{3}{|c|}{ 相 対 湿 度 } \\
\hline & & $10 \%$ & $50 \%$ & $87 \%$ \\
\hline 紙の含水 & & 1 & 8 & 16 \\
\hline 弾性係数 & 無処理紙 & 10.4 & 6.6 & 3.4 \\
\hline " & 処 理 紙 & 10.0 & 7.8 & 5.0 \\
\hline 引張り強さ & $m$ 無処理紙 & 4,200 & 3,300 & 1,800 \\
\hline$" \prime$ & 処 理 紙 & 4,700 & 3,600 & 2,000 \\
\hline 伸 び率 & 無処理紙 & 3.6 & 4.3 & 6.2 \\
\hline "1 & 処 理 紙 & 4.4 & 6.2 & 7.3 \\
\hline
\end{tabular}


の影響を比較した試験表が第 14 表(8)である。 消泡刜

パルプや紙の製造工程中に発生する泡は，まことに やっかいなるのである。この泡を制御するのには

(1) パルプや紙料の中に空気が混入するのを減少す る。

（2）泡の安定性を少くする

というような方法があるが，(1)の場合は機械装置の設 計や操業の仕方と，取扱い原料の洗浄等の問題である が，それだけでは充分ではないので，(2)の目的の為め に薬品の使用が必要になってくる。

それが消泡剤であるが，消泡剂は泡を取り囲こんで いるフィルムの中に入り，それを安定化している分子 に代って，安定化を減じらるような分子に代えること ができるよらな組成をもったものであればよいのであ る。

しかし，このよらに泡の安定性を減じて急速に消滅 させることのできる機能をもった薬品は，シリコンエ マルジョン，シリコン，シリケートエマルジョン高級 アルコール招よびその誘導体，灯油等であるが(6)，泡 を発生させるよらな状態を可能な限りなくした後に適 当に使用すべきであるとされている。

\section{スライムコントロール剤}

スライムはバクテリヤとカビとの混合している微生 物群で，製紙工場の使用水，排水等の中にはそれらの 微生物に適していて食料吕豊富に含まれているから， 各部分に群落をつくっている。

これらの微生物の生育する好適温度は, $20 \sim 40^{\circ} \mathrm{C}$ で

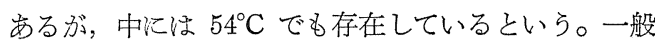
に寒冷地の製紙工場では発生は少いようである。

このような微生物の生育を抑制する方法は

（1）用水の混濁の程度を極力減少する

(2) 殺菌剤を使用する

ことであるが，殺菌剤としては，有機水銀，有機錫， 有機塩素化合物，有機空素化合物等が用いられている ${ }^{(6)}$ 。

しかし，有機水銀剤は微量に使用しても人体にまで 悪影響を及ぼすことを愳念されて，今日では使用され ていない。

添加使用の方法には連続的, 衝撃的, 断続的等があ るが，連続的に使用すると微生物に耐性ができたり， コスト高を招く恐れがある。

歩留補助剂

紙料として，長繊維パルプに代って，広葉樹の短繊 維パルプや砕木パルプ等と填料を配合して，高速度で， 抄造するよらな場合は，ワイヤ下の白水中の固形分の
含有率は益々多くなる。このような固形物は，シート の中にとどまっているべきものなのであるが，その歩 留がよい程, 地合は均斉になることは周知の通りであ る。

白水中の固形物の紙への歩留の補助となる力法につ いては，二つの方法がある。

（1）反対の電荷を与えること。 水中に懸垂している繊維や填料は (一) に負荷されて いる。これに硫酸バンドのような電解質の薬品を添加 すると（十)になってフロックが生成する。フロック は歩留を助けるのである。

更にスビーンニカワ，活性化したシリカゾル，燐酸 ソーダ等を添加すれば，フロックを増し，サイズや地 合を改善し，歩留向上の助けともなる。

(2) 繊維と填料を結合せしめる。

そのために用いられている薬品には，合成高分子物 質にはポリアクリルアミドや其の他のポリアミドがあ り，天然高分子の化工品として化合殿粉执よびその他 の多種類がある。

これらの歩留補助剂や凝集剂字利用するにあたって は，好適な使用条件や経済性を考慮すべきことが注意 されている(8)0

\section{薬品需要量の増大化傾向}

製紙用薬品類の需要量は, 生産高の増加とともに增 して行くには当然であるが，更に従来使われている種 類と異ったものの需要が盛になるであららと考えられ ている。

その理由は，抄紙機が，現在のきまでとどまること なく，一層高速，広幅に移行するであろらが，そのよ らな機械の生産性を抑制している条件に次の三つが数 えられる。

三つの条件とは

(1) 脱水率

(2) 歩留と地合

（3）排水水質の污濁

である。

これらの条件は薬品の機能によって解決せねばなら ないのであるといらことである(9)。

これらの条件の中でも，抄紙原質の脱水の問題は， 抄紙速度を抑制する原因に最も関係がある。

高速度抄紙機では，懸垂状態にある紙料かコロイド 状で，極めて均斉に分散しているものが要求される。

そこで，ある種の高分子物質を，紙匹が構成する前 に，吒解されたパルプに添加すれば，プレスに和ける 脱水率を著しく改善することがでさるといら ${ }^{(9)}$ 。

但しこのよらな薬品は目下，パルプの種類によって 
は屡々効果的に作用しない欠点もあり，価格の点は， ビーター殿粉を最も效率的に利用した場合の 10 倍も 高価である。更に添加量に対する歩留もわるいので高 価格の点以外の理由でもあまり利用されていないが， しかし効率的なこの種の添加物の研究は熱心に進めら れているといら。

一方，紙料の水切れをよくし，脱水率を向上させる ためには，パルプ繊維を機械的に吒解することを少く し，膨潤度を下げてフィブリル化も又減少する傾向と なるが，その対策として利用する添加薬品も増大する であろらことが予測される。

歩留の向上と地合の改善の問題も, 薬品の演じる役 割が強調され, 啓蒙されるようになり, 製品品種の多 様化とともにその量的増加も考えられる。

最後に，排水水質の污濁の問題は，抄紙機の大型化， 高速化, 複雑化飞伴ら添加薬品使用率, 白水の再用率, 損紙, 故紙の使用率等の増大化に原因寸る洵に好まし くない排出物が，何種類かが結合し，または色々の割 合で排出されるであろら。

\section{新刊紹介}

(1)The Physic and Chemistry of Wood Pulp Fibers Published by: TAPPI, Ca $23 \times 15 \mathrm{~cm}$, pp. 348 , 上質印刷紙使用，布装

1. 木材特よび木材繊維の超構造的組織 2. 微細 解剖扣よび電子顕微鏡写真 3. N材繊維に和ける 1 次フイブリルと超構造物フイブリル 4 . セルロース の多形的形状と構造に関する若干の展望 5 . セルロ 一スモデル化合物： $\beta$ - D- セロテトラオーゼの結晶構 造 6. 細胞壁多糖類の超構造的挙動 7. 細胞壁和よ び木質密度に和ける変化 8. 化学的パルプ化中のリ グニン除去の顕微鏡的図形 9. 繊維表面の変態 10 . 化学的方法によるN材セルロースからの繊維特よび紙 の物理的特性の変化 11 . 晶子寸法とフイブリル配向 の繊維特性の関係 12.1 次フイブリルに特ける運動 学的応力 13 . フイブリルの側鎖らせん状構造の最大 引張り強さのためのフイブリル角度 14 . 生長期間内 の繊維の機械的特性の変化性 15 . 個々の木材繊維の 引張り特性に及ぼす充填率，スパン和よび吒解の効果 16. 超音波パルス技術で評価したセルロース材料に和 ける4 個の 2 次転移 17. 熱処理特よび化学処理した スプルースとシラカバの若干の力学的機械的特性の温 度依存性 18. 縦の圧縮に関連する細胞壁に打ける構 造変化 19. 静的曲汭応力下の単純木材パルプ繊維の 流動学 20. 潰れに要する圧縮力に及ぼすパルプの型 と事後処理の効果 21. 木材パルプ繊維の検方向潰れ: 繊維モデル 22. 乾燥した結合繊維の詰物の吸水性
それらの固形分，色，臭気等はいずれも除去されね ばならない。

\section{参考文献}

(1) Casey; Pulp and Paper

(2) C. Earl Libby; Pulp and Paper Science and Technology

（3）成田; 紙業概要

（4）村井, 中西; 製紙工学

（5）紙パルプ技術協会; 故紙処理和よび調成

(6) " " 紙パルプ技術便覽 1971

(7) " " 仕上 化繊紙 合成紙

塗 工

(8) McGraw-Hill; Pulp and Paper Manufacture

(9) Paper makers told their industry exists only because of chemicals. Pulp and Paper March 1970

(10) 紙パルプ技術協会; 紙パルプの種類とその試験法 （原稿受付 昭 16.4.9)

\section{3. フイブリル化，遊離水特よび繊維結合}

以上 23 項から成る。1964 年に TAPPI に創設され た紙の物理委員会 (Paper Physics Committee) が主 催した第 2 回国際会議で行はれた個々の講演を 1 本に まとめたもの。TAPPI の STAP (Special Technical Association Publication) シリーズ No. 8 として刊 行された。原則として各項毎に質疑応答闌と参考文献 を付属させている。

(松井 満)

(2)Design of the Wet End of the Papermachine

Edited by: Mr. F. M. Bolam

Published by : Ernest Benn Limited, London

British Paper \& Board Makers' Association の Technical Section の紙，板紙製造双書第 3 巻として 発行された。編者 Bolam 氏は Section の前専務理 事で在職中は機関誌 Paper Technology の編集長を 兼ねていた。

内容: 1. フローボックス特よびフライス 2. ワイ ヤ部の調整 3. ワイヤ部のロール取付け 4.サクシ ヨンボックス 5. ワイヤの振動 6. ワイヤの取替え 7. ワイヤ部の構成 8. クーチロールのシート移送

9. プレス部の調整 10 . プレス部ロール支持設備お よび固定 11. フェルトの洗浄 12 . プレス部の構成 その他 13. ロール類 (サクションロール以外の)

14. サクションロール 15 . ベアリング 16. ドクタ

- 17. シャワーパイプ 18. 計測 19. 雑の各項か ら成る。索引付き; 総ページ数 332 : 寸法 $23 \times 15 \mathrm{~cm}$; グリーン布装; 価格 £ 6.90

(松井 満) 